\title{
7 The coming of the railways to France, Charles-Valentin Alkan and Hector Berlioz
}

France Was Relatively slow to adopt railways in comparison with Britain, Germany and Belgium. The first railway to open in France was from St. Etienne westwards to Andrézieux in 1827. A limited service from St. Etienne north eastwards to Lyon then opened in 1832. It was in 1837 when the first full railway passenger service from Paris to St Germain began. A combination of reasons accounted for this delay: it was feared that railways would spoil the picturesque countryside; they would damage the water business industry; and on top of this the government was at first slow to make decisions. Under the rule of Napoleon III, state planning meant that by the end of the 1850s many companies had been merged and trunk lines were interconnected to form new networks. Six regional companies were established with five of them radiating out of Paris - Réseaux du Nord, Réseaux de l'Est, Réseaux de l'Ouest, Réseaux de Paris - Orléans, and Réseaux de Paris - Lyon- Méditerranée (PLM). The sixth network, Réseaux de Midi, served the south. This meant that long-distance travel often necessitated connecting to another line in the main hub of Paris. Consequently Paris grew dramatically in terms of population, commercial activity, industry and tourism. Two of the early trunk lines, Paris - Rouen (1843) and Paris - Orleans, had drawn on English technology and expertise, leaving a permanent legacy in the choice of gauge and the left-hand running which, apart from the Paris Metro, is still the practice on much of the doubletrack in France. The earliest locomotives in France were also of British design. ${ }^{1}$

Two notable pieces of railway music were composed in Paris during the early period of French railway construction: Le chemin de fer (1844), a rhythmically exciting piano piece imitating the sounds of a train by Charles-Valentin Alkan; and Le chant des chemins de fer a grand cantata for tenor and six-part chorus 
composed by Hector Berlioz to mark the opening of the Paris to Lille and Brussels railway line in June 1846.

\section{Charles-Valentin Alkan}

Although today Charles Alkan (1813-1888) is a relatively little-known composer, in the early nineteenth century he had a burgeoning career as both a composer and concert pianist which flourished alongside those of Liszt and Chopin (coincidentally his next door neighbour in Paris). Sadly his career did not thrive in the same way as theirs and his work gradually fell into obscurity. After his death, his music was admired by Debussy and Ravel and championed by pianists such as Busoni but it failed to attract a general following. However, since the 1960s, his work has attracted more attention leading to a small but enthusiastic following of aficionados.

Apart from some vocal works, Alkan composed almost exclusively for the keyboard. His 75 works for piano include the gargantuan Twelve studies in all the minor keys, Opus 39, which takes more than two hours to perform and includes a Concerto and a Symphony, both for solo piano. In contrast he also wrote numerous appealing piano miniatures, each portraying a different mood. As well as writing for piano, Alkan wrote several works for the pedalier, a piano fitted with pedals to be played by the feet in the same way as the organ. Unfortunately the pedalier is now obsolete, meaning that an important body of Alkan's music can no longer be heard.

Alkan was an erudite scholar with a wide range of interests including the study of theology. He was particularly interested in the Bible and completed the extraordinary feat of translating it from Hebrew into French. He had a great sense of humour which is evident in one of his wittiest and better known pieces - Funeral march on the death of a parrot - a piece for mixed voices and wind instruments which parodies the composer Rossini who had a penchant for parrots. Alkan had a life which was, in some ways, unconventional and often solitary; today's telling of it is surrounded by stories reinforcing ideas of his eccentricity. Some of these are true, others are not. The Alkan scholar Jack Gibbons has aimed to dispel some of the myths. ${ }^{2}$ One of the most repeated is the story of Alkan's death which is commonly recounted as owing to a bookcase falling on top of him as he reached for a copy of the Talmud from the top shelf. 
The truth is sadder and more prosaic. It seems that although he was trapped by a piece of falling furniture, it was probably a kitchen cupboard. ${ }^{3}$ He never married and he lived alone, consequently it was more than 24 hours before he was discovered and dragged free but he died in his apartment a few hours later.

\section{Le chemin de fer, Op. 27 (The railway) - Charles-Valentin Alkan}

The first line for passenger traffic in Paris was opened on 24 August 1837 by Queen Marie-Amélie, wife of King Louis-Philippe. It ran from Paris to Le Pecq, the St Germain district north-west of central Paris, and was extended to Rouen in 1843. The terminal station in Paris was at Embarcadère des Batignolles which was within walking distance of rue Saint Lazare where Alkan lived at the time so this could be where he first experienced the railway. ${ }^{4}$

Le chemin de fer is thought to be the earliest musical representation of a journey on a steam-train. It had its first performance on 20 October 1844. The pianist was Alkan himself. The piece could be described as a perpetuum mobile - a continuous stream of notes played at a rapid tempo. It opens with a hypnotic regular beat as the train clatters along the tracks, then a stream of semiquavers enters as it hurtles onwards:

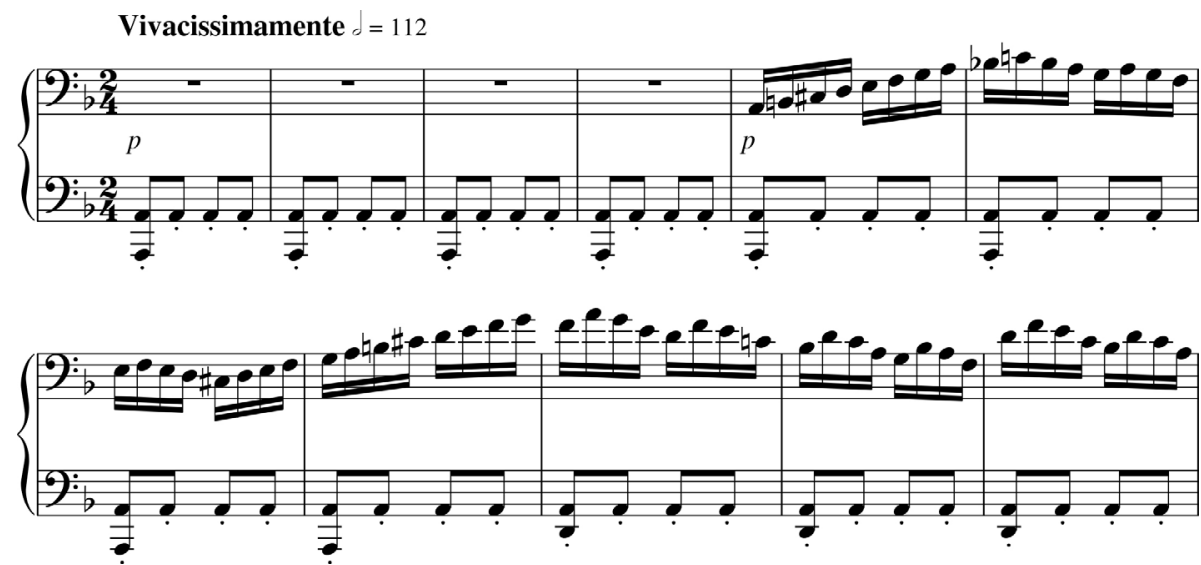

There is only one chord change in the first 52 bars. After 82 bars the relentless semiquaver pace eventually calms down giving way to a bucolic passage with a pastoral melody as the passengers survey the scenery outside. The pace picks up again and we hear a rumbling in the bass as the train belches steam: 


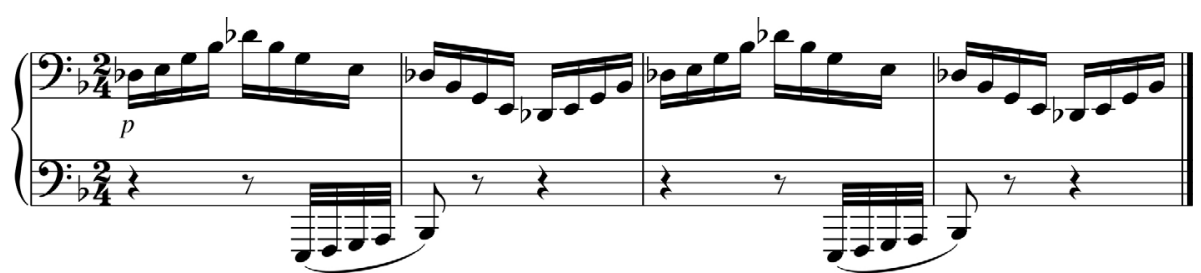

It clatters along and then we hear the sound of a strident whistle in the piano's high register:

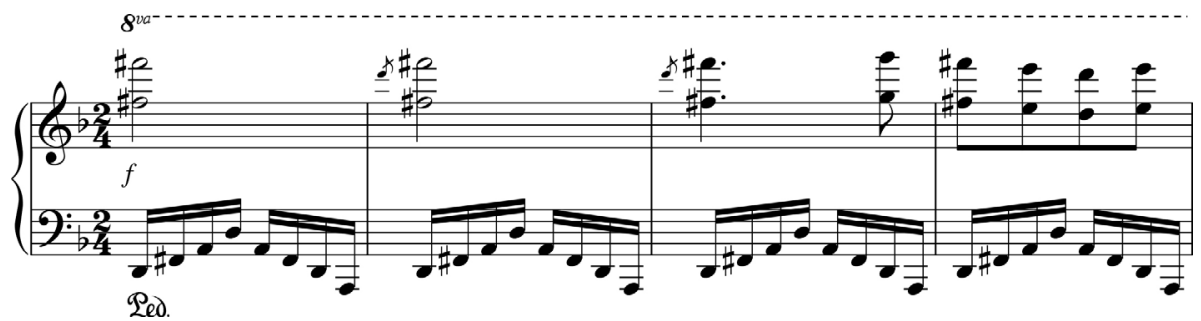

Towards the end of the piece, the train gets slower:

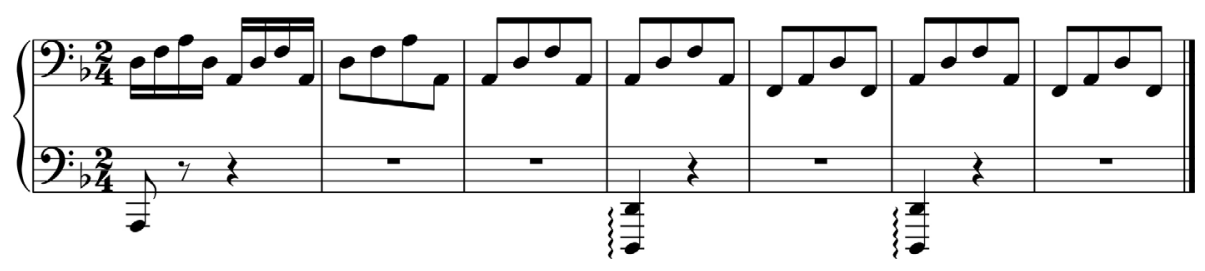

... and slower:

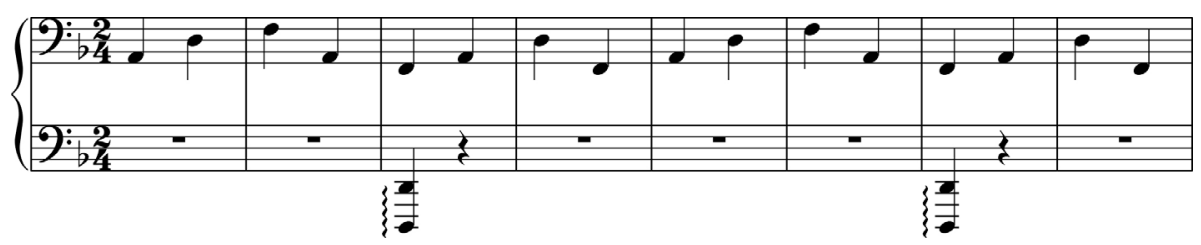


After a final whistle the train enters the station, it slows down and eventually comes to a halt at the journey's end:

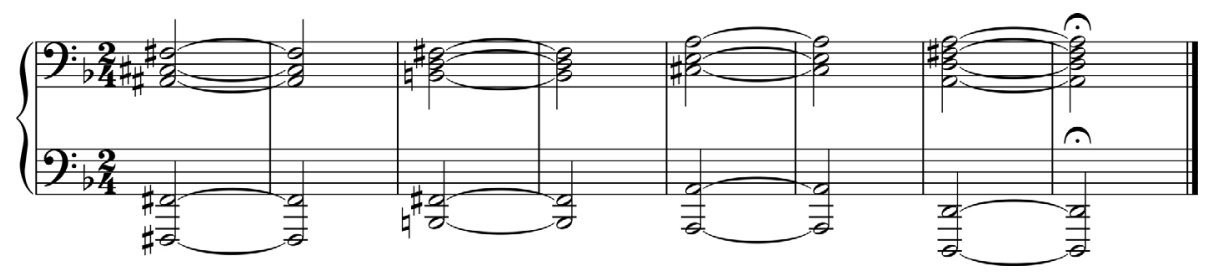

In February 1845, La France Musicale reviewed the recently published piece making a comparison between performing the piece and going on a train journey with all its pleasures and dangers.

We can...upon opening the first score, imagine ourselves sitting down, not at the piano, but in some carriage ready for departure. Can you hear the heavy, regular drumming of the steam train yet? Or, if you prefer, the persistent repetition of the regular figuration in the bass imitating the sound so well? The signal has been given and everything starts moving. You find yourself hurled in an uninterrupted succession of runs of semiquavers in the right hand.... do guard against wrong notes! The speed of the movement may derail you and you will not fail to realise the extent to which an accident might risk your reputation... while the landscape unrolls before our eyes - or at least, the wonderland of sounds captivates our enraptured ears - we will savour the delicacies of a sensual and seductive reverie: this cantabile.. so ingeniously divided between the two hands, invites us so gracefully to let our gaze roam from left to right... Then, ending our musing, we plunge again into the fervent whirlwind that carries us ... The ... rallentando announce, eventually, the end of our route and our étude. And so we have introduced our readers to the concept of imitative music. ${ }^{5}$

Le chemin de fer does indeed bring a certain sense of danger with its tremendous speed and relentless semiquavers - a reflection of the risks posed by train travel in 1844. The review above warns that "The speed of the movement may derail you'. In 1842 France had experienced the worst rail disaster in the world at the time when a train travelling from Versailles to Paris derailed due to a broken axle on the leading locomotive. ${ }^{6}$ The wreckage caught fire, killing as many as 200 people. In terms of the speed of the piece, some have suggested that Alkan's metronome marking was a mistake, being far too fast for anyone to 
play, and that the composer actually meant it to be half that speed. However there are virtuoso performances recorded at the original breakneck speed as indicated in the musical score above. Others have pointed out that at the time of composition trains would not have travelled at any great speed but it must be remembered that steam trains of 1844 would have far exceeded the speed of any other form of transport. Hammond estimates that the train would have been travelling at about $38-55 \mathrm{~km} / \mathrm{h}$ (24 to $34 \mathrm{mph}){ }^{7}$ Although this would be pretty slow-moving by today's standards, it was much faster than the alternative means of transport at the time, the horse drawn carriage, which would have travelled at about $16-24$ (10 to $15 \mathrm{mph})$.

Le chemin de fer was not the only composition of Alkan's to represent mechanics and technology. One of his earliest compositions, Les omnibus (1829), evoked the horse-drawn carriages commonly seen on the streets of Paris. Towards the end of the piece it includes a parody of the postillion's horn. Alkan also used the piano to evoke natural phenomena (Le vent, Op. 15 No. 2, Comme le vent, Op. 39 No. 1, Neige et lave, Op. 67 No. 1 and Gros temps, Op. 74 No. 10) and the animal world (Saltarelle, Op. 23 and Le festin d'Esope).

\section{Hector Berlioz}

Hector Berlioz (1803-1869) is now considered to be the leading composer of the Romantic movement in France. His musical ideas were highly original: he was a pioneer in creating new orchestral sounds; a master of using literature to create a musical narrative; and well-known by students of music as developing the 'idée fixe' where a melody is used to represent a person or an idea throughout an entire musical work - a concept which he developed in his most famous orchestral work, Symphonie Fantastique. During his lifetime however he struggled to find acceptance for many of his new ideas and failed to find a permanent and well-paid position in France. As a musician, he toured Europe a good deal but also earned his living much of the time through writing. He wrote countless articles of musical criticism along with several books notably a comprehensive study of orchestration, the Grand traite d'instrumentation et d'orchestration modernes (1843) and Mémoires (1870). 


\section{Le chant des chemins de fer (The song of the railways)} - Hector Berlioz

Chant des chemins de fer, a huge cantata for tenor, choir and orchestra, was commissioned by the city of Lille to mark the launch of the Paris to Lille and Brussels railway line. It was first performed on 14 June 1846 in Lille. ${ }^{8}$ The moving force behind the commission was the Lille judge Pierre Dubois who was a friend of the writer and critic Jules Janin, the author of the libretto. Berlioz received the commission on his return from a successful European concert tour. Whilst touring he had composed the bulk of a large-scale work for voices and orchestra - La damnation de Faust - but, keen to work on such a rare French commission, he dropped everything. He wrote to his friend and fellow music critic August Ambros.

I am very busy with Faust, but I have just been forced to interrupt my work to write several feuilletons and a cantata which I am due to conduct in Lille for the celebration of the opening of the Northern Railway. ${ }^{9}$

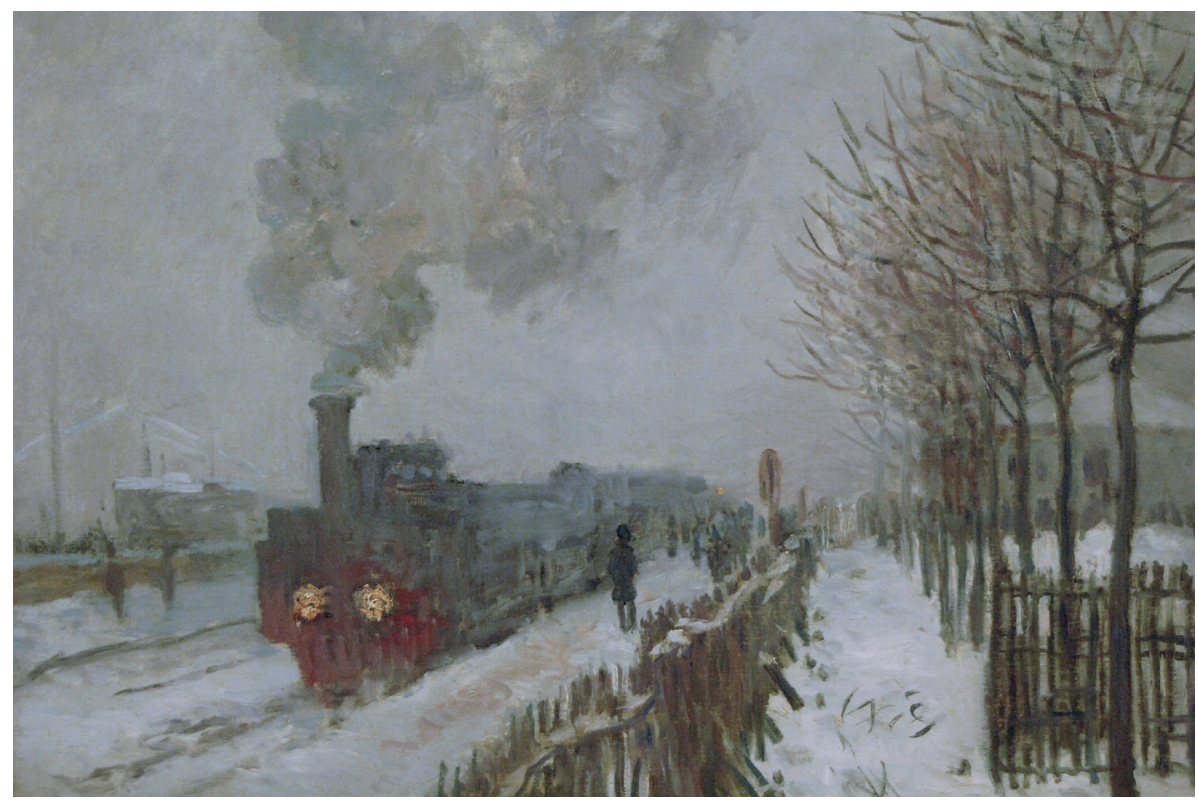

Claude Monet (1840 - 1926) Train in the Snow (the Locomotive), 1875, Musee Marmottan, Paris. PRISMA ARCHIVO / Alamy Stock Photo 
The work was written at great speed over a couple of days. Berlioz later observed that 'I'm quite aware that if I'd had three full days to devote to this piece, my score would live forty centuries longer.' He made several further references to the cantata's composition and performance in letters to his friends, but the most extensive and entertaining description can be found in his book Les grotesques de la musique (Musical Madhouse), a light-hearted collection of witticisms, letters and anecdotes about his life as a composer in mid-nineteenth century Paris. ${ }^{10}$ Le chant des chemins de fer appears in the section of the book which describes various concerts of Berlioz's music given in the provinces. The description takes the form of a letter opening with the words 'I don't expect you have any desire to know why I went to Lille. I'll tell you anyway...The Northern railway, so celebrated for the little accidents to which it was prone, had just been completed. ${ }^{11}$ Here Berlioz was referring to a recent derailment near Arras where there were several fatalities. ${ }^{12}$ He continues - 'His Grace the Archbishop was to give it his solemn blessing, which promised to be an occasion for copious eating and drinking. ... a cantata was needed, to be performed, not after dinner, but before the opening of the ball'. The ceremony was to open with an outdoor military band performance of the 'Apothéose', the finale from Berlioz's Grande symphonie funèbre et triomphale (1840). ${ }^{13}$

As soon as Berlioz reached Lille, Dubois put him in touch with the singers, orchestral musicians and military bands who would be performing the piece. Berlioz was very impressed with the 'excellent small orchestra' and the young singers, writing that these young singers had excellent voices, and mastered the difficulties of the cantata in a very short time. He was much less impressed by the massed military bands describing their playing as 'nothing but earsplitting cacophony'. Much to Berlioz's amusement and surprise, Dubois also had plans to include pyrotechnics and cannon fire in the 'Apothéose' to 'produce a deafening effect'. In the event the first 'rocket shot up with such force it seemed to be heading for the moon' and the concert began. Another rocket shot up at the appointed bar in the coda in readiness for the cannon fire which would end the piece. Sadly the linstocks, the firing equipment for the cannon, hadn't arrive in time so 'A profound silence fell after the last bar, a majestic, grand, immense silence, disturbed an instant later only by the applause of the multitude, apparently satisfied with the performance' and quite convinced that the two rockets it had heard and seen whooshing up with showers of sparks were simply an new orchestral effect.' Following the calamitous outdoor 
performance Berlioz hurried to the town hall to conduct what was to be an excellent performance of Le chant des chemins de fer. ${ }^{14}$

Our singers and musicians had not a breath nor a semiquaver to reproach themselves about. The same could not be said for the audience. After the concert, while I was listening to the gracious words the Duke of Nemours and his brother, the Duke of Montpensier, were good enough to say to me, some autograph collector did me the honour of stealing my hat. I was pained by this...I found myself compelled to go out bareheaded, and it was raining. ${ }^{15}$

Berlioz wrote of the verses of Janin's libretto 'they were fashioned in a certain manner which I shan't attempt to characterise, but which attracts music like ripe fruit attracts birds, quite unlike the great volleys of hemistichs ${ }^{16}$ which professional librettists fire off. ${ }^{17}$ The composer appeared to be pleased with Janin's libretto, but Alastair Bruce, in the notes of his English translation of Les grotesques de la musique, is unequivocal when he writes 'His verses for Le chant des chemins de fer...were exceedingly banal., ${ }^{18}$

\section{Le chant des chemins de fer}

Refrain: It is the big day, the feast day,

Day of triumph and laurels.

For you workers,

The crown is ready.

Soldiers of peace,

It is your victory;

The glory of so many blessings is yours .

\section{Refrain}

The bells ring at dawn,

And the cannon responds on the ramparts.

Under the tricolour banner

The people run from all sides.

\section{Refrain}

How many erased mountains!

So many rivers crossed!

Human labor, fertile sweat!

What wonders and what labour!

\section{Refrain}

The old men, in front of this spectacle, With a smile will descend to the tomb;

For their children this miracle

Makes the future bigger, more beautiful.

\section{Refrain}

The wonders of industry

We, the witnesses, must sing

Peace! The king! The worker! The homeland!

And trade and its benefits!

It is the big day, the feast day,

Day of triumph and laurels.

May the happier people in the countryside so beautiful

By friendship raise their solemn voices

To God hidden in the heavens!

The piece, which lasts roughly 10 minutes, is not one of the composer's greatest works, but it is entertaining and fit for purpose; a festive celebratory work, 
written for large forces and triumphant in mood. It opens with a rousing introduction in a bright major key, loud and fast with rapid woodwind scales and fanfare-like brass heralding the entry of the solo tenor declaiming 'It is the big day' rising up and then falling:

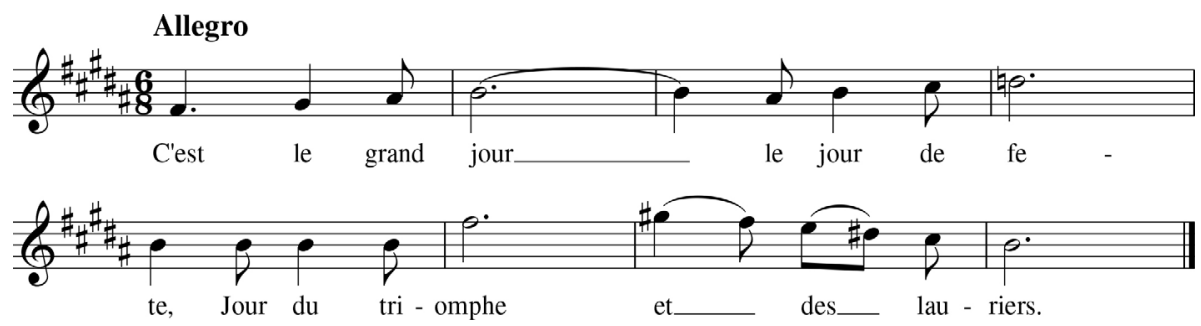

Next the full six-part choir enter with the words "For you workers, "The crown is ready' with busy repeated quavers. The triumphant first refrain concludes with crashing cymbals and huge orchestral chords. Janin was a keen Saint-Simonian, as was Berlioz for a brief period during the 1830 s. $^{19}$ Saint-Simonianism was inspired by the ideas of Claude Henri de Rouvroy, Comte de Saint-Simon (1760-1825) one of the founding fathers of French Christian socialism. Some writers, notably Pierre-René Serna, believe that Saint-Simonianism is evident in the libretto given that it includes some of the philosophy's key themes such as 'the wonders of industry', 'peace' and 'workers'. The refrain, he argues, could be interpreted as celebrating the 'big day', the advent of a new society, reflecting the Saint-Simonian ideology with its vision of an industrialized society where the workers were recognised and fulfilled. ${ }^{20}$

The mood changes with the third verse at the words "The old men, in front of this spectacle, With a smile will descend to the tomb; For their children this miracle, Makes the future bigger, more beautiful'. In this calm hymn-like prayer, the music slows down, the time signature changes and the bass voices of the choir are now accompanied only by slow-moving strings. The fourth verse could be described as a paean to 'Peace! 'The king! The worker! The homeland!'. This section has a grandiose choral treatment where the soloist alternates with the choir in imitation, accompanied by trumpet fanfares, cymbal crashes and big bold chords. The whole piece builds up towards the end, with full choir and orchestra, punctuated by brass chords and cymbal crashes.

It has to be said that Le chant des chemins de fer is rarely performed. Notable performances in the United Kingdom include one in 1975 at the Royal Albert 
Hall celebrating the 150th anniversary of the Stockton and Darlington Railway and another in 1994 at the launch ceremony of the Eurostar service. There are also few recordings. One interesting recording was made exactly 120 years after its composition when the French railway company SNCF organised a performance by the railway workers' symphony orchestra as part of the International Railway Congress Association conference in Paris. ${ }^{21}$ 


\section{Endnotes}

1 Christian Wolmar. The Golden Age of European Railways. (Barnsley: Pen \& Sword Transport, 2013): 65-86

2 http://www.jackgibbons.com/alkanmyths.htm

3 Ibid.

4 Nick Hammond and Frederick Keygnaert. "Le Chemin de Fer". The Alkan Society Bulletin no. 96 (April 2018), 15.

5 La France Musicale, 9 Feb, 1845.

6 The accident happened on 8 May 1842 between Versailles and Paris following celebrations at the Palace of Versailles to mark King Louis Philippe's saint's day. 16 to 18 carriages carrying around 770 passengers, who were locked in their compartments, were being hauled by two steam locomotives. The leading locomotive broke an axle and derailed at Meudon. The second locomotive and the carriages behind piled into it and caught fire, seriously injuring hundreds and resulting in the deaths of between 52 and 200 people. Following this accident the custom of locking passengers in was abandoned.

7 Alkan Society Bulletin, no 96, April 2018

8 The piece exists in two versions: the original cantata for tenor and six-part chorus; and a later arrangement as No. 3 of his Feuillets d'album, Op.19.

9 http://www.hberlioz.com/France/Lille.htm

10 Hector Berlioz. The Musical Madhouse. Translated by Alastair Bruce. (Rochester: The University of Rochester Press, 2003).

11 This is the 'Third letter', an abridged form of a piece which originally appeared in the Revue et Gazette Musicale on 19 November, 1848.

12 According to the Illustrated London News (July 18, 1846) on July 8, 1846 a train from Paris derailed having recently passed through Arras station. The Northern Railway Company reported that 12 or 14 carriages derailed with five or six of them falling down a bank into deep water resulting in 12 fatalities. The ILN noted that other reports had put the number of deaths much higher.

13 Berlioz, Musical Madhouse, 177.

14 Berlioz, Musical Madhouse, 186-188.

15 Berlioz, Musical Madhouse, 188.

16 A hemistich is a poetic device, a half line of verse often separated rhythmically from the rest of the line by a caesura.

17 Berlioz, Musical Madhouse, 178.

18 Berlioz, Musical Madhouse, 209.

19 Berlioz, Musical Madhouse, 190.

20 Pierre-René Serna explores the elements of Saint-Simonian feeling in Social Songs and Paths of Utopia. http://www.hberlioz.com/Special/prserna.htm

21 The French railway company Société Nationale des Chemins de Fer Français (SNCF) invited the Orchester Symphonique des Cheminots and La chorale de oratoire, under the direction of Robert Blot, to perform the piece as part of the 1966 International Railway Congress Association conference in Paris. 